DOI: https://doi.org/10.47405/mjssh.v6i11.1190

\begin{tabular}{|c|c|}
\hline & Malaysian Journal of Social Sciences and Humanities (MJSSH) \\
\hline Malaysian Journal of & Volume 6, Issue 11, November 2021 \\
\hline (MJ-SSH) & e-ISSN : 2504-8562 \\
\hline & $\begin{array}{l}\text { Journal home page: } \\
\text { www.msocialsciences.com }\end{array}$ \\
\hline
\end{tabular}

\title{
Kesan Pembangunan Angkatan Tentera Malaysia (ATM) Terhadap Keselamatan Negara Pasca Perang Dingin
}

\author{
Ahmad Shah Pakeer Mohamed', Mohamed Fajil Abdul Batau', Muhamad Ridzuan Hashim² \\ 1Faculty of Administrative Science and Policy Studies, Universiti Teknologi MARA (UiTM), Malaysia \\ ${ }^{2}$ Senior Assistant Director, State Planning Unit (Terengganu), Malaysia \\ Correspondence: Ahmad Shah Pakeer Mohamed (ahmad7243@uitm.edu.my)
}

\begin{abstract}
Abstrak
$\overline{\text { Melihat kepada konsep persekitaran serantau bagi golongan fahaman realis, sistem antarabangsa itu }}$ sendiri merupakan satu keadaan yang terdedah kepada ancaman keselamatan dan persaingan kuasa. Dengan ini ia memerlukan proses keseimbangan kuasa bagi menjamin keselamatan negara-negara dalam sistem antarabangsa. Keadaan ini kerana bagi realis isu keselamatan sesebuah negara merupakan perkara penting dan kepentingan keselamatan negara dalam sistem antarabangsa adalah untuk mempertahankan sempadan wilayah dan melindungi nilai-nilai utamanya. Dalam konteks Malaysia, tidak dinafikan persaingan kuasa juga memainkan peranan yang penting dalam mencorakkan pertahanan negara. Persaingan antara kuasa besar dan ketidaktentuan kuasa besar dunia sememangnya mengubah dimensi dan cabaran negara dalam mempertahankan kepentingan negara. Melihat dari keadaan sistem antarabangsa, menerangkan hubungan kuasa-kuasa besar menjadi semakin sukar diramal. Malaysia mencapai kemerdekaannya pada 1957 dalam situasi persaingan kuasa ketika era Perang Dingin. Keadaan ini secara tidak langsung mempengaruhi pembentukan serta pembangunan angkatan tentera negara di dalam mencari kaedah yang baik bagi mengekalkan survival keselamatan negara di rantau Asia Tenggara.
\end{abstract}

Kata kunci: keselamatan, ancaman, ATM, Perang Dingin

\section{The Effect on Malaysian Armed Forces (MAF) Development Towards Malaysian National Security Post Cold War}

\begin{abstract}
The concept of a regional environment by realists, the international system itself is a situation that is vulnerable to security threats and power competition. With this it requires a process of balance of power to ensure the security of countries in the international system. This situation is because for realists' the issue of state security is an important matter and the importance of states to protects its national security in the international system and defend territorial borders as well as protect its core values. In the Malaysian context, there is no doubt that competition for power also plays an important role in shaping the country's defense. Competition between superpowers and the uncertainty of world superpowers are indeed changing the landscape and challenges of nations in defending its national interests. Judging from the state of the international system, explaining the relationship of the great powers is becoming increasingly difficult to predict. Malaysia achieved its independence in 1957 in a situation of power competition during the Cold War era. This situation indirectly affects the formation
\end{abstract}


and development of the Malaysian Armed Forces in finding good methods to maintain its national security and their survival in the Southeast Asian region.

Keywords: security, threats, MAF, Cold War

\section{Pengenalan}

Keruntuhan Kesatuan Soviet (SU) pada tahun 1991, telah mempengaruhi aspek ancaman keselamatan dalam geo-politik antarabangsa. Tamatnya persaingan kuasa antara AS dengan SU yang turut dilihat telah membawa kepada "kestabilan" dan "keamanan" kepada sistem antarabangsa. Perkembangan ini turut mempengaruhi dimensi definisi keselamatan yang tidak hanya dilihat dipengaruhi oleh isu-isu tradisional, sebaliknya soal keselamatan turut dikaitkan dengan isu-isu bukan tradisional (non traditional issues atau new security issues) seperti isu ekonomi, alam sekitar, kemanusiaan dan sebagainya. Ancaman keselamatan terhadap negara di rantau Asia Tenggara khususnya Malaysia lahir dari dalam rantau ini dan turut melibatkan dimensi yang lebih luas iaitu dari luar rantau dan antarabangsa. Menurut Mohammed Ayoob (1995), keselamatan mempunyai dua tanggapan iaitu ancaman keselamatan dari luaran atau luar sempadan. Kedua ialah ancaman lain yang turut melibatkan ancaman ketenteraan. Dengan kata yang lain, konsep keselamatan boleh dilihat dari dua sudut iaitu keselamatan dalaman dan keselamatan luaran. ${ }^{1}$ Menurut Zakaria Haji Ahmad (1987), ancaman negara Malaysia yang terdekat adalah dari kalangan negara yang berhampiran (negara jiran) seperti Indonesia, Thailand dan Singapura. Walaupun pada ketika ini hubungan Malaysia dengan ketiga-tiga negara adalah baik, namun ia tidak bermakna tiada ancaman daripada negara berkenaan. Ini adalah selaras dengan perspektif realisme yang menjelaskan 'struggles for power' adalah nature kepada negara dan peperangan sesuatu yang tidak boleh dielakkan. ${ }^{2}$

Ancaman keselamatan bukan tradisional adalah perkara yang jarang diberi perhatian oleh masyarakat, akan tetapi perkara itu boleh memberi ancaman kepada negara atau suasana setempat, malahan boleh menimbulkan konflik dalam hubungan di antara negara. ${ }^{3}$ Ancaman ini merupakan ancaman bukan melibatkan ketenteraan tetapi merupakan ancaman baru yang muncul seperti terorisme, penyakit, bencana alam dan pelbagai bentuk 'human security' yang lain. Sebagai contoh kes serangan kumpulan pengganas yang dikenali sebagai kumpulan Al-Maunah pada Julai 2000, seramai 20 orang pengganas yang telah menceroboh kem ATM iaitu Batalion 304 Infantri, Gerik, Hulu Perak dan mencuri 97 senjata M16, empat GPMG, lima pelancar grenad, 9,095 butir peluru 5.56mm dan 60 butir peluru $40 \mathrm{~mm}$ adalah merupakan perkara yang mampu menggugatkan keamanan negara. ${ }^{4}$ Malah Insiden seperti pencerobohan kumpulan pemberontak di wilayah Lahad Datu, Sabah pada tahun 2013, telah memaksa ATM melancarkan Ops Daulat yang berjaya mengusir penceroboh itu. Seramai 71 orang militan dari wilayah Sulu terbunuh dengan sejumlah 10 anggota keselamatan Malaysia yang terkorban. Ini merupakan contoh bagaimana ancaman keselamatan bukan tradisional akhirnya menjadi satu peristiwa berdarah yang mampu menggugat keselamatan di rantau Sabah dan negara.

Selain itu, lokasi strategik Sabah yang merangkumi pulau-pulau yang berselerak dan garis pantai di sepanjang 1.557 kilometer, yang bukan hanya menjadikan negeri ini rentan terhadap pencerobohan, tetapi juga terpaksa menghadapi pendatang haram seperti (PATI) dan juga masalah pelanunan dari kumpulan bersenjata atau militan dari negara jiran. Sebagai contoh, pencerobohan pelanunan pada 23 April 2000, seramai 20 orang ditawan dan dijadikan tebusan. Ini termasuk tawanan pekerja dari Sipadan Resort, pelancong dan kakitangan Agensi Hidupan Liar Malaysia. Penculikan itu dilakukan

\footnotetext{
${ }^{1}$ Mohammed Ayoob (1995). Op.cit.hlm 5

${ }^{2}$ Ibid.

${ }^{3}$ The Malaysian Insider (2015) Masyarakat Asean perlu faham ancaman keselamatan bukan tradisional, kata penganalisis sesi temubual dengan penganalisis Dr Azmi Hassan Pakar Geostrategis dari Universiti Teknologi Malaysia (UTM).

https://www.yahoo.com/news/masyarakat-asean-perlu-faham-ancaman-keselamatan-bukan-tradisional051918085.html

${ }^{4}$ Izwan Rozlin Dan Ahmad Ismadi Ismai (2020).Al-Maunah Tewas Di Bukit Jenalik. Sinar Harian. 14 Mac 2020
} 
oleh kumpulan Abu Sayyaf yang berasal dari Filipina, dan kumpulan ini juga dilabel sebagai pengganas. ${ }^{5}$ Pengganas tersebut bersenjatakan senapang AK47 dan bazooka semasa kegiatan penculikan tersebut. Dua insiden berlaku pada 2013, yang pertama pada 27 Ogos, apabila kira-kira 20 lelaki bersenjata menculik sembilan nelayan Malaysia dari dua bot berhampiran Pulau Mabul. Dalam pada itu, pada 15 November, kumpulan lelaki bersenjata menyerbu tiga daripada lima vila terapung di Pulau Pom Pom. Ketika pencerobohan itu, pelancong Taiwan, Hsu Lin Min, 57, terbunuh, dan isterinya Chang An Wei, 58, diculik. Selepas 36 hari, Chang An Wei dibebaskan oleh penculik dan kembali dari pulau Jolo di selatan Filipina ${ }^{6}$ Selain itu, peningkatan bilangan masyarakat Malaysia yang terlibat dalam kegiatan militan sebagai contoh terdapat laporan penglibatan rakyat Malaysia dalam Negara Iraq dan Syria (ISIS) dan di beberapa negara ASEAN. Hanya kerana terpengaruh dengan ideologi yang kononnya bertopengkan agama telah membuktikan betapa ancaman keselamatan bukan tradisional ini mampu menjurus kepada gejala ekstremisme. ${ }^{7}$ Keadaan seperti ini memaksa perlunya negara melaksanakan pembangunan ATM pasca Perang Dingin walaupun dilihat negara berada di dalam keadaan selamat dan tiada ancaman yang serius.

\section{Kesan Ancaman Terhadap Pembangunan Pertahanan Malaysia}

Semenjak negara mencapai kemerdekaan, Malaysia telah membangunkan dasar dan angkatan tentera dalam melindungi keselamatan dan kedaulatannya. Pembangunan pertahanan semenjak tahun 1957 serta pemodenan ATM bermula semenjak tahun 1990an telah membolehkan negara mengekalkan kedaulatannya. Umumnya semenjak tahun 1957 hingga 2019, pembangunan dasar dan pertahanan negara Malaysia telah melalui satu tempoh fasa yang panjang dengan pelbagai dimensi bentuk ancaman. ${ }^{8}$ Ancaman keselamatan juga turut berkembang yang bukan hanya tertakluk kepada ancaman keselamatan tradisional seperti persempadanan, konflik, krisis dan peperangan (use of force). Sebaliknya selepas tahun 1991 ancaman keselamatan semakin berevolusi dan berkembang yang turut melibatkan ancaman bukan tradisional seperti ancaman pengganas (terorisme), dadah, ekonomi, penyakit, pertikaian sempadan dan sebagainya yang mampu meruntuhkan sesebuah negara. ${ }^{9}$ Melihat dari ketidakpastian lingkungan strategi negara di rantau Asia Tenggara, khususnya konflik intra-rantau dan masalah terorisme lintas negara yang semakin meningkat memaksa Malaysia menjalankan pembangunan dan memodenkan angkatan tentera agar dapat setanding atau jika tidak lebih baik dibandingkan dengan negara jiran lain. Malaysia perlu meningkatkan pembangunan ATM agar memberikan ketumbukan kekuatan di luar perairan sempadan daratan serta lautan. ${ }^{10}$

\section{Pembangunan Angkatan Tentera Malaysia (ATM) Pasca Perang Dingin}

Pembangunan atau modenisasi Angkatan Tentera Malaysia (ATM) merupakan antara gerakkan awal bagi negara untuk mentransformasikan sesebuah pasukan angkatan ATM bagi menjadikan sebuah pasukan yang seimbang, sangat berwibawa, bersepadu dan sentiasa bersedia dalam menghadapi cabaran dalam sebarang konflik yang hadir. Kepesatan pembangunan ATM jelas dapat dilihat dengan tindakan kerajaan memberi penumpuan pembangunan dalam aspek DPN, Strategi, Logistik, Bajet, Industri Pertahanan dan Hubungan Luar. Ini kerana menurut Kogila Balakrishnan (2008), ${ }^{11}$ Sukma. R

\footnotetext{
${ }^{5}$ Abu Sayyaf mengganas sejak 1990-an. Harian Metro. 26 April 2016

6 T. Avineshwaran (2014) Kawasan Kes Culik Di Resort Semporna Ada Banyak Sejarah Penculikan Lain. Akhbar Mstar. 3 April.

https://www.mstar.com.my/lokal/semasa/2014/04/03/kawasan-kes-culik-di-resort-semporna-ada-banyak-sejarahpenculikan-lain

${ }^{7}$ ibid

${ }^{8}$ K.S Nathan (2008) Op. Cit. hlm 9. Lihat juga Bradley R. Simpson (2013). Southeast Asia in the Cold War. Dalam Robert J. McMahon (Edt). The Cold War In The Third World. Oxford: Oxford University Press.hlm 52-58

${ }^{9}$ Muslim, N., \& Alias, J. (2004). Op. Cit.

${ }^{10}$ Shaharuddin Othman (2002). Malaysian Armed Forces Modernisation: Would It Enhance National Development? Faculty Of Social Sciences And Humanities: Universiti Kebangsaan Malaysia.

${ }^{11}$ Kogila Balakhrishnan (2008) Defence Industrialisation in Malaysia Development Challenges and the Revolution inMilitary Affairs. Security Challenges, Vol. 4, No. 4 (Summer 2008), pp. 135-155
} 
dan K. S. Nathan (2009), ${ }^{12}$ Jaswant S. Sidhu (2009) ${ }^{13}$ dan Abdul Razak Baginda (2009) ${ }^{14}$ menyatakan kepesatan pembangunan ATM berskala besar bermula selepas Perang Dingin. Negara Malaysia membuat pembelian beberapa aset untuk memantapkan cabang-cabang di dalam sektor perkhidmatan ATM juga dilihat sangat tepat dan ianya adalah sebagai salah satu tanda aras dalam menyelaraskan hasrat ATM bagi menjadikan ATM sebagai salah satu organisasi yang cekap dan sentiasa dalam keadaan siapsiaga. Walaupun begitu, sektor-sektor yang lain di dalam unit-unit ketenteraan juga perlu diberikan perhatian serta dibangunkan dan ditingkatkan agar ia selari dan sentiasa relevan demi menjaga keselamatan negara. ${ }^{15}$ Merujuk kepada Dato Sri Mohd Najib Tun Razak (2006) ATM sentiasa komited dan bersedia di dalam melaksanakan tanggungjawab, amanah serta peranannya sebagai benteng terakhir negara. ATM bukan hanya memfokuskan kepada pembelian aset untuk kegunaan ketenteraan yang bersifat canggih semata-mata. ${ }^{16}$ Asas-asas lain juga dilihat sangat penting seperti industri pertahanan (DI), pembangunan sumber yang sangat optimum, serta penglibatan luar negara atau kerjasama dengan kuasa-kuasa besar dunia. Kerjasama serantau juga dilihat sangat penting membantu negaranya untuk sentiasa bersiap sedia mempertahankan lokasi strategik dan memelihara keselamatan negara berasaskan kepada prinsip-prinsip peningkatan keupayaan berdikari, pertahanan menyeluruh, diplomasi serta kerjasama serantau serta pemodenan angkatan tentera. ${ }^{17}$

Rajah 1: Komponen Aspek Pembangunan (ATM) di Malaysia ${ }^{18}$

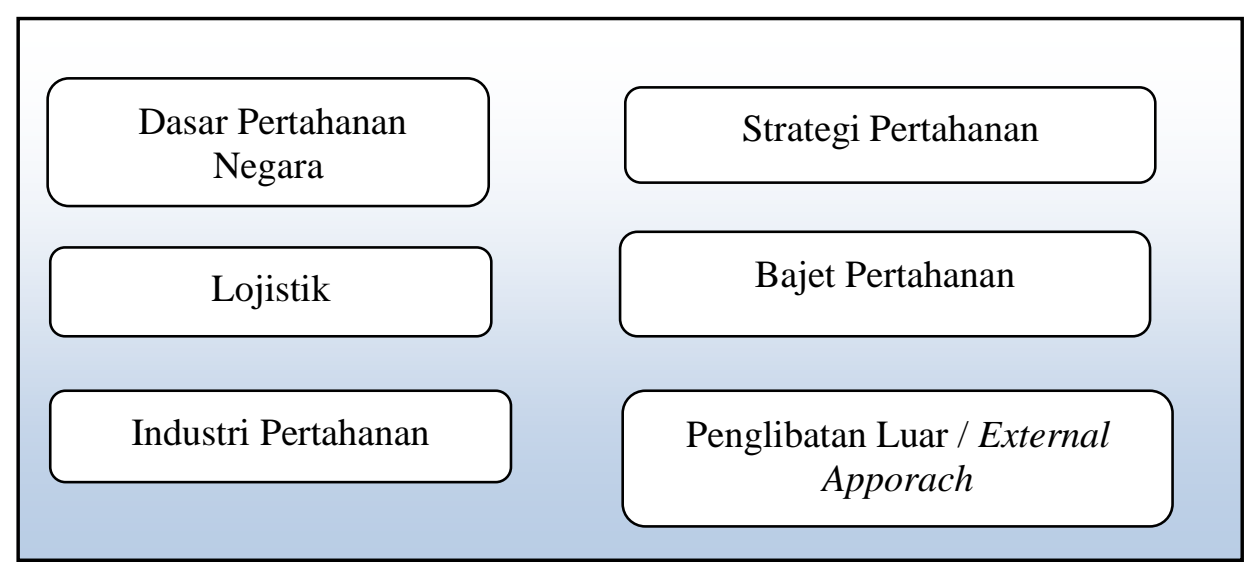

Pembangunan ATM dilihat amat drastik pada pasca Perang Dingin dengan memperlihatkan pembangunan ATM ke arah untuk mewujudkan pemodenan angkatan tentera. Menurut Kogila Balakrishnan (2008), beliau menyatakan negara Malaysia memulakan pemodenan tentera secara berskala besar dan juga membuat peningkatan teknologi sejak dari awal tahun 1990an. ${ }^{19}$ Menurut juga sarjana-sarjana yang lain seperti S Jayasankaran (2002), Jaswan S. Sidhu (2009) dan Abdul Razak Baginda (2009), ini dapat merumuskan secara keseluruhan bahawa modenisasi pembangunan dan pertahanan ATM dilihat telah melengkapi pembangunan ATM di ketiga-tiga unit iaitu TUDM, TLDM dan TDM pada pasca Perang Dingin. Keadaan ini dapat dilihat dengan pembelian aset-aset yang baru

\footnotetext{
12 Sukma, R. and K.S. Nathan (2009) 'Globalization's Impact on Threat Perceptions and Defence Postures in Southeast Asia: Two Views', dalam G. Till, E. Chew and J. Ho (eds), Globalization and Defence in the Asia-Pacific, Abingdon: Routledge. Hlmn 90-120

${ }^{13}$ Sidhu, Jaswant S. (2009). Op. Cit.

${ }^{14}$ Abdul Razak Baginda (2009) Op. Cit.hlm 1-30

${ }^{15}$ Noraini Zulkifli (2016), Kepentingan Nasional Jepun Di Selat Melaka: Kerangka Teori Dan

Konseptual. Sumber diekses dari

https://www.researchgate.net/publication/326987998_Teori_Realisme_dan_Neo_Realismepdf

${ }^{16}$ Dato' Sri Mohd Najib Tun Abdul Razak (2006). semasa ucapan Penggulungan Bajet 2007 di Peringkat

Dasar di Dewan Rakyat. http://www.pmo.gov.my/ucapan/?m=p\&p=najibtpm\&id=3587

${ }^{17}$ Kementerian Pertahanan Malaysia (2006) Laporan Tahunan Kementerian Pertahanan Malaysia

${ }^{18}$ Sumber diambil dan diolah dari kajian tesis kajian Dr Mohamad Faisol Keling (2016). Dasar

Pertahanan Negara Malaysia : Analisis Ke Atas Prinsip Pertahanan Self-Reliance. Tesis Kajian Doktor

Falsafah (PhD). Kolej Undang-Undang, Kerajaan Dan Pengajian Antarabangsa, Universiti Utara

Malaysia. Februari

${ }^{19}$ Kogila Balakrishnan (2008). Op.cit m/s 135-155
} 
dari negara kuasa besar seperti negara Britain, negara Amerika Syarikat dan negara Rusia dengan asetaset yang dibeli adalah seperti jet pejuang dan helikopter seperti F/A-18s, C-130s, F-5s, A-4s serta $\mathrm{H}$ 3. Kerajaan Malaysia juga membuat pembelian 18 unit jet pejuang MIG-29 Fighter. ${ }^{20}$ Pembelian yang lain adalah seperti Jet pejuang seperti HAWK MK108, pesawat sukhoi SU30MKM dari negara Rusia, kereta kebal ADNAN armoured combat vehicles, PT-91m, kapal selam Scorpene dari negara Perancis, Astros II dari negara Brazil dan G5 MKIII peluru berpandu jarak dekat, senjata Styer Sniper serta beberapa unit Kapal Perang Tempur. ${ }^{21}$ Secara keseluruhannya dapat dilihat bahawa ATM telah diberi nafas baru semasa dalam pentadbiran Dato Sri Mohd Najib Tun Razak kerana dilihat ketika itu Malaysia telah mula melaksanakan pembangunan ATM secara drastik ke arah pertahanan berdikari. Jika dilihat dengan rekod Dato Sri Mohd Najib Tun Razak dilantik selama dua kali (1990-1995 dan 1999-2008) banyak perubahan yang telah ATM laksanakan bertujuan membangunkan serta memodenkan ATM ke tahap yang lebih baik. Namun ianya juga dilihat masih tidak cukup untuk melabelkan ATM pada hari ini telah dimodenkan dan dibangunkan secara drastik kerana masih terdapat lagi lompang-lompang yang terpaksa dibaiki oleh ATM.

\section{Kelemahan Pembangunan Angkatan Tentera Malaysia (ATM) Pasca Perang Dingin.}

Pembangunan dasar dan ATM juga mempunyai masalah dan cabaran walaupun dapat pembangunan yang dilaksanakan oleh ATM sehingga hari ini yang dilihat menunjukkan peningkatan yang positif. Namun begitu, ada juga para sarjana melihat pembangunan dan pemodenan ATM pasca Perang Dingin masih mempunyai kelemahan dan kelompangan. Melihat dari segi Dasar Pertahanan Negara (DPN) terdapat para sarjana yang menyatakan bahawa DPN mempunyai beberapa kelemahan. Menurut Jaafar Kasim (2002), menyatakan telah membincangkan beberapa kelemahan dalam prinsip DPN iaitu terdapat kelemahan yang meragukan dalam pelaksanaan prinsip Pertahanan Berdikari dalam DPN. ${ }^{22}$ Manakala menurut Shaharuddin Othman (2002) menyatakan dengan menjelaskan bahawa objektif mengukuhkan DPN bagi mencapai prinsip pertahanan berdikari memerlukan kesungguhan serta komitmen dari kerajaan iaitu kementerian serta ATM itu sendiri agar DPN lebih menjadi komprehensif dan bukannya hanya sebuah "buku rekod" atau "buku teks" yang hanya menceritakan tentang penerangan semata-mata. ${ }^{23}$ Pendapat ini juga telah dikritik oleh Abdul Razak Baginda (1995) di dalam tulisannya "Malaysia's Defence \& Foreign Policies" dengan menyatakan perlunya satu bentuk dasar pertahanan yang mengambil kira pembangunan dan keselamatan secara komprehensif dan sistematik (firm defence posture) ${ }^{24}$ yang dapat dijadikan sebagai ketetapan dan hala tuju yang jelas dalam pembangunan dan pemodenan ATM. ${ }^{25}$ Manakala menurut Farouk Kamal (2000), dalam tulisan "Defence Minister of Malaysia Najib Tun Abdul Razak Articulating Malaysia's Defence" telah mengkritik DPN dengan menyatakan kerajaan Malaysia tidak hanya membentuk DPN yang hanya berteraskan dan memfokuskan kepada ancaman tradisional semata-mata. ${ }^{26}$ Dengan ini dapat dilihat walaupun terdapat evolusi dan pembangunan terhadap DPN namun ada di antara sarjana mengkritik pembangunan DPN. Menurut Hendrik Wagenmakers (1995) menyatakan pembangunan ketenteraan yang lebih sistematik akan dijadikan rujukan serta pendirian kepada dasar pertahanan sesebuah negara. Manakala ketelusan kerajaan dalam pembangunan dan pemodenan ATM serta merangka rancangan

\footnotetext{
${ }^{20}$ Abdul Razak Baginda (2009). Op.cit m/s 24-27

21 ibid

22 Jaafar Kasim (2002) Influence Of Bureaucratic Politics On Ministry Of Defence Decision Making Process In Policy Formulation. Tesis. Faculty Of Social Science And Humanities: Universiti Kebangsaan Malaysia.hlm 32-36

${ }^{23}$ Sebagai maklumat tambahan, maklumat ini pernah dilaporkan oleh P.K Sengupta dan Muhammad Fuad Mat Nor (2002). Cabaran ATM Dan Pemodenan TD. Perajurit. September. hlm 2-7

${ }^{24}$ Abdul Razak Abdullah Baginda. \& Rohana Mahmood (1995) Malaysia's Defence \& Foreign Policies. Petaling Jaya, Selangor Darul Ehsan, Malaysia. Pelanduk Publications.

${ }^{25}$ ATM sememangnya memerlukan DPN yang jelas dan Kertas Putih Pertahanan (Defence White Paper) dalam membangunkan pertahanan dengan kukuh. Maklumat ini turut disentuh daripada sesi temubual dengan Ketua Setiausaha Kementerian Pertahanan, Datuk Seri Mohd Zuki Ali. Ibu pejabat Kementerian Pertahanan, Jalan Padang Tembak. Kuala Lumpur pada 21 November 2019 dan juga maklumat ini turut diperolehi daripada sesi temubual dengan Timbalan Ketua Setiausaha (Dasar). Y.BRS Tuan Ahmad Nadzri Mohd Hassan. Ibu pejabat Kementerian Pertahanan, Jalan Padang Tembak. Kuala Lumpur pada 29 May 2019.

${ }^{26}$ Farouk Kamal (2000). Defence Minister of Malaysia Najib Tun Abdul Razak Articulating Malaysia's Defence. Asian Defence and Diplomacy. Oktober. hlm 25
} 
pembangunan ketenteraan dengan tepat pada masanya dan berkesan perlu menjadikan rancangan yang dirancang dalam DPN selaras dengan pembangunan ATM. ${ }^{27}$

Melihat dari sudut strategi pertahanan dilihat juga terdapat kelemahan dari sudut pembangunan ATM. Menurut Jeneral Tan Sri Dato' Sri Azizan Ariffin TUDM (2009) Kerajaan perlu membangunkan ATM dengan peralatan strategik, berteknologi tinggi dan canggih, dan mempunyai kelebihan dalam kualiti, kuantiti, dan kemampuan untuk memastikan bahawa maklumat kemampuan Malaysia dapat mencapai tahap cegah rintang yang diingini, realitinya masih lagi lemah dan perlu di bangun dan dimodenkan. ${ }^{28}$ Ia dikritik oleh K.S Balakrishnan (2009), menyatakan tentang strategi HANRUH adalah sesuatu yang kabur dari segi penerimaan dan aplikasi oleh agensi kerajaan masih kurang. Rakyat masih lagi tidak faham dengan peranannya terhadap menjaga keselamatan negara bersama dalam konsep HANRUH. ${ }^{29}$

Melihat dari sudut pembangunan logistik terdapat beberapa juga kelemahan yang telah dikritik oleh para sarjana. Menurut M. Haniff Ismail (2008), pembelian aset ketenteraan memfokuskan kepada aset terpakai. Aset terpakai sangat berisiko tinggi. Dalam aspek logistik pembelian aset ketenteraan yang telah digunakan seperti pembelian aset (Secondhand) dan berisiko tinggi untuk rosak. Contoh pada tahun 1988 Malaysia telah membuat pembelian terbesar TUDM iaitu 88 buah pesawat pejuang Skyhawk dan pembelian kelengkapan pertahanan yang lain adalah lebih dipengaruhi oleh harga dan tidak berkualiti. ${ }^{30}$ Manakala menurut M. Haniff Ismail (2008), pembelian aset ketenteraan memfokuskan kepada aset-aset terpakai. Aset terpakai sangat berisiko tinggi untuk rosak. ${ }^{31}$ Maklumat ini juga di kritik oleh Datuk Mohd Reza Mohd Sany (2019) yang menyatakan aset logistik ATM khususnya TLDM seperti kapal KD Perdana yang berusia 46 tahun masih mampu berlayar di lautan dan melakukan perkara asas. TLDM turut mengakui aset yang dimiliki TLDM sangat usang dan sudah berusia puluhan tahun. ${ }^{32}$ Masalah aset yang terhad juga menjadi kekangan kepada pembangunan logistik ATM dan perkara ini di sokong oleh Menurut Azmi Md Deros (2004) menyatakan bilangan aset yang terhad ini juga menyebabkan wujudnya lompong dalam jaringan pertahanan negara. ${ }^{33}$ Keadaan ini adalah disebabkan masalah pembelian aset yang tidak konsisten. Menurut Liew Shan Lee (2016) menyatakan pada masa kini nampaknya tidak ada perolehan untuk membuat pembelian secara konsisten, akan tetapi ia hanya untuk memberi peluang kepada syarikat tempatan memiliki teknologi bagi membangunkan aset ketenteraan berkapasiti tinggi. Namun, peluang yang diberikan oleh kerajaan untuk sebilangan besar syarikat ini belum digunakan sepenuhnya. ${ }^{34}$

Melihat dari sudut masalah pembangunan bajet ATM Menurut Lt Kol Soteto Bin Soejalmo (1999) menyatakan pasca Perang Dingin memperlihatkan peruntukan bajet untuk pertahanan dilihat tidak menentu dan tidak mencukupi untuk pembangunan dan pemodenan ATM. Peruntukan belanjawan pertahanan berkisar antara dua hingga 3\% dari KDNK direkodkan setiap tahun dilihat masih lagi tidak mampu untuk menampung pembangunan dan pemodenan ATM yang dilihat sangat memerlukan bajet yang besar. ${ }^{35}$ Penyataan ini disokong oleh S. Jayasankaran (2002), telah menyatakan jumlah

\footnotetext{
${ }^{27}$ Hendrik Wagenmakers (1995). The UN Register Of Convensional Arms, In Arms And Technology Transfer: Security and Economic Considerations Among Importing and Exporting States. New York: United Nations. hlm 7581

${ }^{28}$ Jeneral Tan Sri Dato' Sri Azizan Ariffin TUDM (2009). Panglima Angkatan Tentera Ke-17. Maklumat diperolehi daripada Teks Rasmi Perintah Ulung Jeneral Tan Sri Dato' Sri Azizan Ariffin TUDM Panglima Angkatan Tentera Ke-17. 30 September 2009. hlm 2

${ }^{29}$ Kogila Balakrishnan (2009). Malaysia's Defence Policy, Military Modernisation And National Security. Dalam Abdul Razak Baginda (pnyt). Malaysia's Defence \&Security Since 1957. Kuala Lumpur: Malaysia Strategic Research Centre. hlm 117-118

${ }^{30}$ M. Haniff Ismail (2008) Pembelian Aset Terpakai Satu Pandangan. Majalah Perajurt, Julai. ms 14-19

31 ibid

32 Hafidzul Hilmi Mohd Noor (2019). Scorpene Masih Berbisa. Harian Metro. 14 November 2019. https://www.hmetro.com.my/mutakhir/2019/11/517217/scorpene-masih-berbisa

${ }_{33}$ Azmi Md Deros (2004). Super Hornet Pastikan Ruang Udara Lebih Selamat. Berita Harian. 15 Mei 2004 hlm5.

Lihat juga Sharanjit Singh (2018) Tun M-Putin Bincang Isu Jet Pejuang, Hubungan Dua Hala. Harian Metro. 14 November 2018

https://www.hmetro.com.my/mutakhir/2018/11/394992/tun-m-putin-bincang-isu-jet-pejuang-hubungan-dua-hala

${ }^{34}$ Liew Shan Lee (2016) Defence Asset Procurement Policy - Logistical Consideration. Mei 16

http://themalaysianpatriot.blogspot.com/2016/05/defence-asset-procurement-policy.html

${ }^{35}$ Lt Kol Soteto Bin Soejalmo (1999) How Successful Is The Modernization Of The Malaysia Armed Forces. Maktab Pertahanan Angkatan Tentera Malaysia. Edisi Terhad. Hlmn 1-9
} 
perbelanjaan pertahanan negara Singapura pada 2002 ialah $5.1 \%$ berbanding $2.03 \%$ perbelanjaan Malaysia daripada Keluaran Dalam Negara Kasar (KDNK). ${ }^{36}$ Kekangan bajet juga menyebabkan pembangunan logistik ATM tidak dapat dikembangkan. Perkara ini disokong oleh Choong Wah (2017) yang menyatakan pengurangan bajet pada tahun 2017 sebanyak 2 billion dari tahun sebelumnya akan menyebabkan logistik, latihan serta operasi tiga perkhidmatan ATM di ketiga-tiga cabang iaitu darat, laut dan udara akan terjejas. Keadaan ini dipengaruhi oleh kurangnya kepekaan kerajaan Malaysia terhadap fungsi keseluruhan ke atas sumber logistik. ${ }^{37}$ Kekangan bajet pasca Perang Dingin ini adalah disebabkan oleh krisis ekonomi yang telah melanda negara pada pasca Perang Dingin yang memberi kesan kepada pembangunan pertahanan. Penyataan ini disokong oleh Muhammad Fuad Mat Nor (2002) yang menyatakan krisis kewangan 1997 memberikan kesan kepada Kementerian Pertahanan Malaysia dan pembangunan ketenteraan serta hala tuju ATM. ${ }^{38}$

Melihat dari komponen Industri Pertahanan, pembangunan industri pertahanan pada masa kini adalah terhad. Malaysia dilihat sebagai negara pengguna bukan negara yang mengeluarkan produk. Keadaan ini yang menyebabkan pembangunan dasar dan ATM dilihat menghadapi masalah pembangunannya. Menurut Mohd Basri Nordin (1999) menyatakan:

\section{"Sebagai sebuah negara pesat membangun di rantau ini, Malaysia tidak seharusnya menjadi negara pengguna semata-mata. Kita sepatutnya bangkit dengan idea dan teknologi sendiri paling tidak menjalinkan usaha sama" ${ }^{\prime 39}$.}

Dalam pada itu, Menurut Liew Chin Tong (2019) yang merupakan Timbalan Menteri Pertahanan pada 4 April menyatakan negara Malaysia kekurangan jenama dan barangan yang boleh dieksport. Walaupun negara banyak menganjurkan pameran industri pertahanan seperti "The Defence Services Asia Exhibition \& Conference" (DSA) ${ }^{40}$ dan "Langkawi International Maritime and Aerospace Exhibition" (LIMA) ${ }^{41}$ namun pameran ini lebih menunjukkan jenama besar luar negara yang menjual sesuatu yang kita mungkin tidak perlukan. Negara seperti Korea Selatan, Turki, Indonesia dan Singapura merupakan contoh negara yang mempunyai industri pertahanan yang kecil 30 tahun lalu tetapi kini bertambah baik dengan senarai produk untuk dieksport yang membanggakan dalam satu generasi. ${ }^{42}$ Manakala Liew Chin Tong (2019) menyatakan, sebahagian besar yang ada dalam industri pertahanan negara ketika ini ialah 'ejen komisen' atau 'posmen' yang menjual senjata sebagai ejen tempatan kepada KPM dan ATM mewakili pengeluar asing. ${ }^{43}$

Manakala melihat dari sudut komponen hubungan luar menurut Liew Shan Lee (2020), cabaran utama negara adalah agar ATM tidak terlalu bergantung dengan pendekatan luar dan terlalu berasa selesa kerana keadaan ini akan membuatkan ATM alpa untuk melaksanakan pembangunan serta pemodenan ATM dengan drastik. Sebagai contoh dapat dilihat melalui pakatan perjanjian FPDA, kewujudan FPDA ini telah memberi "false sense of security" kepada Malaysia secara keseluruhannya walaupun pembangunan ATM pasca Perang Dingin memperlihatkan terdapat peningkatan dalam membangun dan memodenkan ATM namun begitu masih terdapat beberapa masalah yang dilihat oleh para sarjana

\footnotetext{
${ }^{36}$ S. Jayasankaran (2002). Op. Cit.hlm 20

${ }^{37}$ Ibid

${ }^{38}$ P.K Sengupta dan Muhammad Fuad Mat Nor (2002). Cabaran ATM Dan Pemodenan TD. Perajurit. September. hlm 2-7

${ }^{39}$ Mohd Basri Nordin (1999). Keperluan Industri Pertahanan Dalam Membentuk Perajurit ATM Abad Ke 21. Perajurit. Mei

${ }^{40}$ The Defense Services Asia adalah merupakan pameran perdagangan dan persidangan untuk teknologi pertahanan dan sistem keselamatan. Ia adalah salah satu pameran terpenting seumpamanya di dunia. Pameran ini adalah platform komunikasi dan maklumat dalam industri dan menawarkan peluang kepada syarikat pameran untuk menyampaikan kepada khalayak pakar di sini. Maklumat di sunting dari

https://www.tradefairdates.com/Defence-Services-Asia-M11238/Kuala-Lumpur.html

${ }^{41}$ Pameran Maritim \& Aeroangkasa Antarabangsa Langkawi (LIMA) adalah pertunjukan terbesar seumpamanya di rantau Asia Pasifik. Senarai pameran dan pembekal antarabangsa yang mengagumkan lebih banyak dibandingkan dengan kehadiran elit industri yang menyokong, mulai dari pegawai kanan Kerajaan, dan perwakilan tentera dan sipil, hingga penggerak industri dan banyak lagi. Sinar Harian (2019) LIMA'19 melabuhkan tirai dengan lakar kejayaan Artikel Penuh :

https://www.sinarharian.com.my/article/20922/BERITA/Nasional/LIMA19-melabuhkan-tirai-dengan-lakar-kejayaan

${ }^{42}$ Liew Chin Tong (2019) Industri pertahanan pemangkin ekonomi negara. Sinar Harian. 4 April.

${ }^{43}$ ibid
} 
yang merasakan masih terdapat kelemahan dan lompang dalam pembangunan ATM pasca Perang Dingin. ${ }^{44}$

\section{Isu Kesiapsiagaan ATM Yang Memberi Kesan Terhadap Keselamatan Negara}

Terdapat beberapa isu-isu penting yang berlaku melibatkan negara yang telah memperlihatkan tahap kemampuan kesiapsiagaan ATM yang rendah dan lemah. ${ }^{45}$ Tahap kesiapsiagaan yang tinggi merupakan perkara yang utama di dalam sesebuah negara. Perkara ini juga telah disebut dalam objektif kedua Pertahanan Menyeluruh, perlunya mengekalkan kesiapsiagaan yang berterusan serta mempunyai keupayaan untuk membendung sebarang ancaman. ${ }^{46}$ Namun begitu masih terdapat beberapa isu berkenaan pertahanan yang penting melibatkan keselamatan negara yang gagal dibendung dan dikekang oleh ATM.

\section{Isu Militan Al-Maunah (2000)}

Kredibiliti ATM khususnya kesiapsiagaan ATM telah dipertikaikan dengan kegagalan ATM mengawal aset dan kemnya. Di dalam kes serangan pengganas kumpulan Al-Maunah pada Julai 2000 yang terdiri daripada 20 orang pengganas, mampu menceroboh sebuah kem ATM iaitu Batalion 304 Infantri, Gerik, Hulu Perak dan mencuri 97 senjata jenis M16, serta empat GPMG, lima pelancar grenad, 9,095 butir peluru $5.56 \mathrm{~mm}$ dan 60 butir peluru $40 \mathrm{~mm} .{ }^{47}$

Rajah 2: Keratan Akhbar Mengenai Pencerobohan Kumpulan Al-Maunah ${ }^{48}$

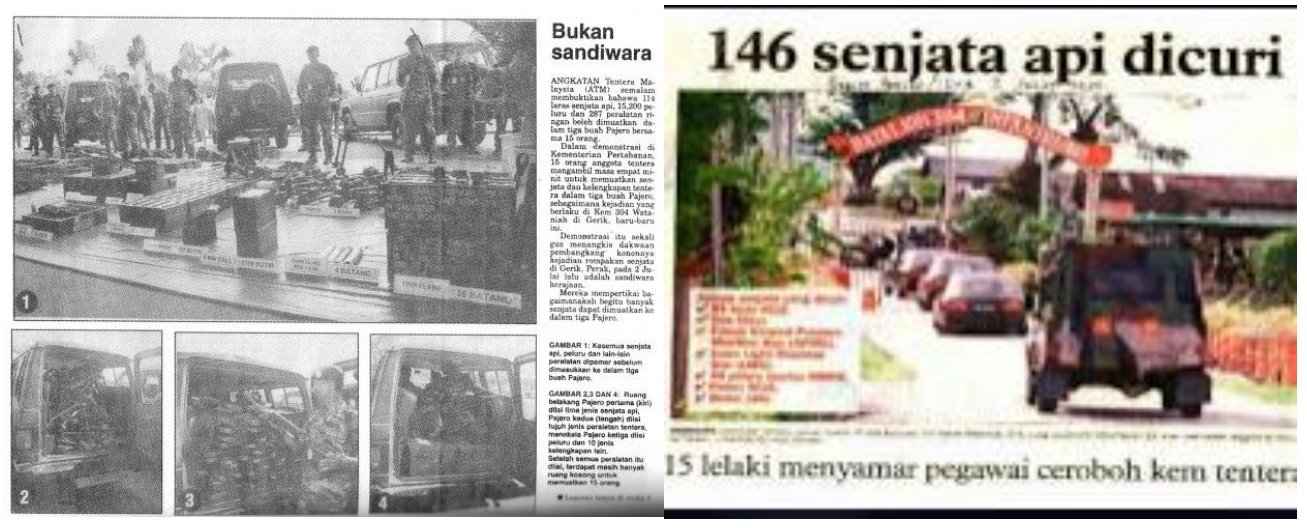

Kes ini telah menjadi penanda aras mengenai kelemahan kawalan ATM dan menunjukkan ketidakupayaan angkatan tentera negara yang gagal di dalam mempertahankan sebuah kem dengan hanya dari serangan 20 orang pengganas Al-Maunah yang mampu melarikan senjata api milik ATM. Ini bermaksud tahap siapsiaga ATM gagal mempertahankan dan mengawal sebuah kem daripada dicerobohi oleh pengganas. Pengganas ini kurang memiliki latihan tetapi mampu menceroboh dan menawan sebuah kem tentera yang dikawal penuh dan malah mampu merampas senjata ATM. ${ }^{49}$ Serangan pengganas Al-Maunah pada Julai 2000 telah menjadi ukuran bahawa keupayaan ATM dan pembangunan ATM yang dilihat lemah. ${ }^{50}$

\footnotetext{
${ }^{44}$ Liew Shan Lee (2020) FPDA - Relevan? Atau Perencat Pembangunan Pertahanan Negara? 18 Januari. http://themalaysianpatriot.blogspot.com/2020/01/fpda-relevan-atau-perencat-pembangunan.html

${ }^{45}$ Mohd Bustamam Mat Zain (2005). Comprehensive Security Policy - The Singapore Case. Bangi:UKM.

${ }^{46}$ Jurnal Tentera Darat Malaysia, Revolusi Dalam Hal Ehwal Ketenteraan, KEMENTAH: Sorotan Darat, Bil 43, Jun 2004, hIm 78.

${ }^{47}$ Izwan Rozlin Dan Ahmad Ismadi Ismai (2020). Op. Cit.

${ }^{48}$ Zabidi Mohamed (2010) Al-Maunah: Kebenaran Yang Sebenar (The Naked Truth). Malaysia. Zabidi Publication dan Nadzim Ahmad Jamalludin; Hassan Omar; Jalal Ali Abdul Rahim; Safuri Kamaruddin (2000) 146 senjata api dicuri. Berita Haria. 3 Julai.

${ }^{49}$ Seven Al-Ma'unah Members Plead Guilty To Alternative Charge. Utusan Malaysia. 5 Disember 2000.

${ }^{50} \mathrm{ibid}$
} 


\title{
Isu Pencerobohan Lahad Datu (2013)
}

Melihat dari kes pencerobohan lahad Datu pada 2013, memperlihatkan tahap keupayaan dan siapsiaga aset ATM telah menjadi persoalan apabila pencerobohan itu berlaku pada 12 Februari dan telah mengancam kedaulatan negara.

Rajah 3: Keratan Akhbar Mengenai Pencerobohan Pengganas Di Lahad Datu ${ }^{51}$

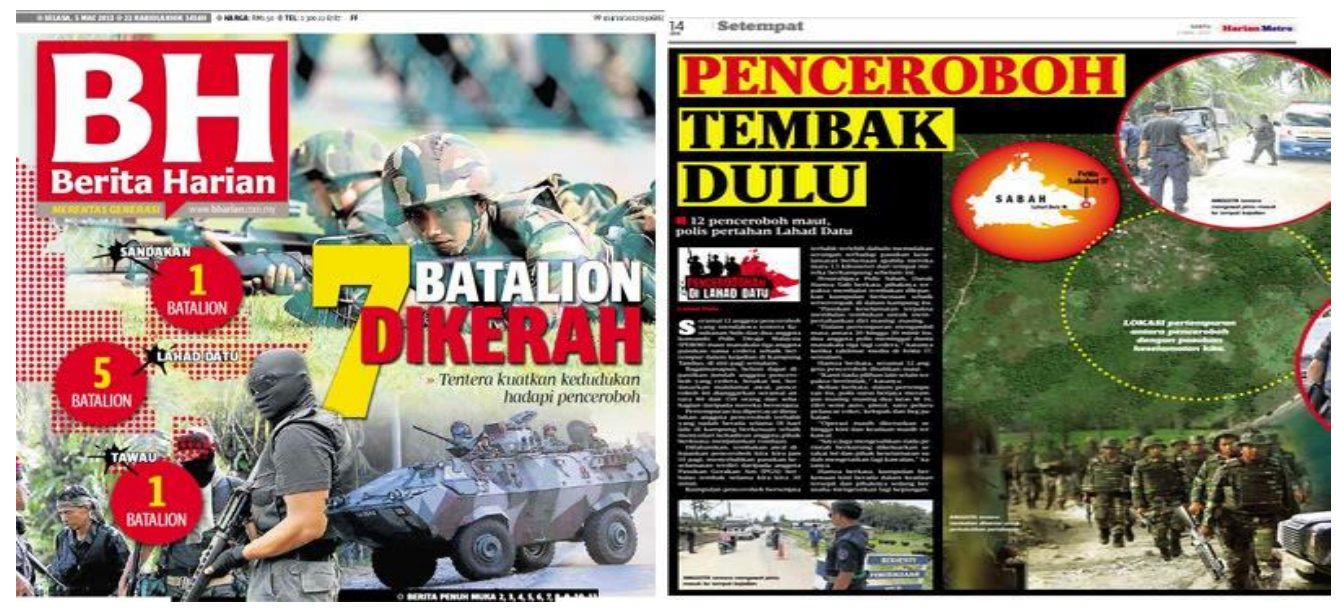

Pencerobohan Lahad Datu, Sabah ini dilakukan oleh 200 orang pengganas militan bersenjata dari kepulauan Sulu, Selatan Filipina. ${ }^{52}$ Pencerobohan telah menjadi kayu ukur kepada kelemahan logistik ATM dan pasukan keselamatan kerana ATM, Polis serta perisikan negara telah gagal untuk mengesan kemasukan pencerobohan itu ke dalam wilayah negara. Menurut Panglima Angkatan Tentera Jeneral Jeneral Tan Sri Dato' Sri (Dr.) Haji Zulkifeli Mohd Zin (2014) menyatakan:

\begin{abstract}
"Ancaman tradisional dan bukan tradisional semakin kabur yang menjadi semakin mencabar. Peristiwa pencerobohan Lahad Datu Sabah pada Februari 2013 adalah menjadi bukti ATM tidak boleh lagi alpa dan leka. ${ }^{53 . "}$
\end{abstract}

Insiden pencerobohan ini telah mencemarkan imej ATM kerana ATM gagal melindungi dan menjaga keselamatan negara. ${ }^{54}$ Menurut Dato' Seri Hishammuddin Tun Hussein (2014), menjelaskan, serangan kumpulan pengganas telah memberikan kesedaran kepada Malaysia khususnya ATM untuk mengambil tindakan serius bagi meningkatkan tahap siapsiaga keupayaan aset logistik ATM supaya keselamatan negara dapat dijamin..$^{55}$

\section{Pencerobohan Sempadan Perairan dan Pendatang Tanpa Izin (PATI)}

Selain itu, lokasi strategik di kawasan perairan Sabah dan Sarawak merangkumi pulau-pulau yang berselerak dan garis pantai di sepanjang 1.557 kilometer, menjadikan negeri ini rentan terhadap

\footnotetext{
517 Batalion dikerah. Berita Harian. 5 Mac 2013. Hlm 1-5 dan Penceroboh Tembak Dulu. Harian Metro. 2 Mac 2013

${ }^{52}$ Pencerobohan Di Lahad Datu Pengajaran Berguna Kepada Malaysia-PM Utusan Malaysia. 12 Mac 2013

${ }^{53}$ Jeneral Tan Sri Dato' Sri (Dr.) Haji Zulkifeli Mohd Zin, Panglima Angkatan Tentera (2014). Maklumat Perutusan Rasmi Teks Rasmi Perutusan Jeneral Tan Sri Dato' Sri (Dr.) Haji Zulkifeli Mohd Zin. Di Acara Perbarisan Sempena Hari Angkatan Tentera Malaysia ke-81. Di Dataran Panglima Tentera Darat. Kem Perdana Sungai Besi pada17 September 2014. hlm 5-7

${ }^{54}$ Lihat penjelasan kelangsungan hidup negara dalam Martin Griffiths dan Terry O'Callaghan (2002). International Relations, The Key Concepts. London: Routledge. Untuk melihat kelangsungan hidup atau the survival of the states mengikut pendapat realis, sila rujuk Kenneth Waltz (1979). Theory Of International Politics. Massachusetts: AdisonWesley. Hlm 131. Lihat juga John J. Mearsheimer (1995). The False Promise Of International Institutions. International Security. Vol 19. Bil. 3. Winter.hlm10

55 YB. Dato' Seri Hishammuddin Tun Hussein, Menteri Pertahanan (2014). Maklumat diperolehi daripada Teks Rasmi Perutusan YB. Dato' Seri Hishammuddin Tun Hussein, Menteri Pertahanan Malaysia. Majlis Perutusan Menteri Pertahanan Tahun 2014. Wisma Pertahanan, Kementerian Pertahanan pada 25 Februari 2014. hlm 4
} 
pencerobohan sempadan dan juga masalah pelanunan dari kumpulan bersenjata dari negara-negara jiran. Sebagai contoh pencerobohan pelanunan pada 23 April 2000, seramai 20 orang ditawan dan dijadikan tebusan. ${ }^{56}$ Ini termasuk pekerja Sipadan Resort, pelancong dan kakitangan Agensi Hidupan Liar Malaysia. Penculikan itu dilakukan oleh kumpulan Abu Sayyaf yang berasal dari Filipina, dan juga dilabel sebagai pengganas.

\section{Rajah 4: Keratan Akhbar Mengenai Pencerobohan Sempadan Negara ${ }^{57}$}

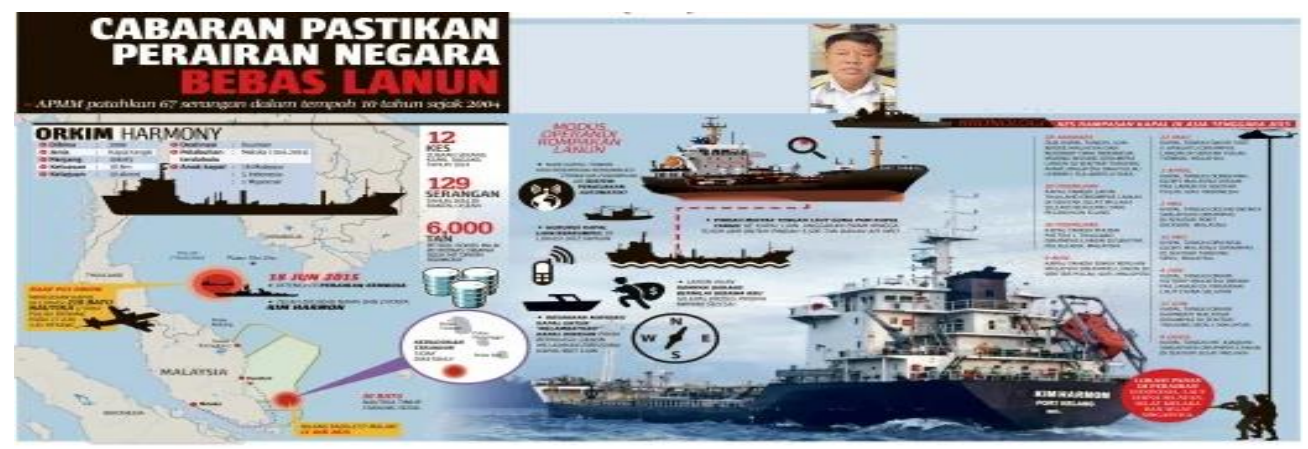

Pengganas bersenjatakan senapang AK47 dan bazooka semasa kegiatan penculikan tersbut. Dua insiden berlaku pada 2013, yang pertama pada 27 Ogos, apabila kira-kira 20 lelaki bersenjata menculik sembilan nelayan Malaysia dari dua bot berhampiran Pulau Mabul. Dalam pada itu, pada 15 November, kumpulan lelaki bersenjata menyerbu tiga daripada lima vila terapung di Pulau Pom Pom. Ketika pencerobohan itu, pelancong Taiwan, Hsu Lin Min, 57, terbunuh, dan isterinya Chang An Wei, 58, diculik. Selepas 36 hari, tebusan dibebaskan oleh penculik dan kembali dari pulau Jolo di selatan Filipina $^{58}$ manakala isu mengenai PATI bukan merupakan perkara yang tidak asing lagi. Ini kerana isu kemasukan imigran tanpa izin ini telah lama menjadi polemik dan masalah keselamatan negara. Melihat kepada situasi semasa, laluan atau lorong tikus merupakan tumpuan bagi aktiviti jenayah rentas sempadan yang perlu diberi perhatian atas faktor ancaman yang bukan sahaja mengganggugugat kedaulatan negara malah risiko tindakan penjenayah yang boleh memberi ancaman keselamatan kepada anggota ATM itu sendiri. ${ }^{59}$ Dengan pelbagai siri pencerobohan perairan negara memperlihatkan tahap keselamatan negara di kawasan perairan masih rendah dan ia akan menyebabkan pencerobohan berlaku secara berleluasa. Tahap siapsiaga ATM dilihat lemah kerana gagal mengekang isu pencerobohan sempadan negara.

\section{Kesimpulan}

Konsep yang realisme menekankan kepada keutamaan negara untuk saling bergantung kepada diri sendiri (self reliance) di dalam aspek keselamatan bagi menjaga kepentingan negara. Ia adalah disebabkan negara kini telah dipengaruhi oleh keadaan sistem antarabangsa yang seperti tiada undangundang dan bersifat anarki dan sifat sesebuah negara adalah sentiasa mahu terus bersaing di antara satu sama yang lain. ${ }^{60}$ "Fenomena anarki" telah mempengaruhi kebanyakan negara untuk memberikan tumpuan dan perhatian terhadap pembangunan Angkatan ketenteraan bagi menjamin keselamatan untuk tujuan kelangsungan hidup. Manakala merujukkan kepada teori neo-realisme, teori ini mengatakan dilema keselamatan sebagai situasi yang sentiasa ada ancaman yang cuba untuk menggugat keselamatan negara mahupun ianya dari bentuk unsur ancaman tradisional mahupun dari unsur dari ancaman bukan dari tradisional. Akibat dari senario keselamatan dan sifat anarki dalam sistem antarabangsa, keadaan ini akan menyebabkan negara perlu bergantung pada diri sendiri untuk kelangsungan hidup. Ini merujuk kepada konsep self help atau self reliance di mana setiap negara mempunyai kepentingan negara mereka tersendiri dalam meneruskan kelangsungan hidup dalam

\footnotetext{
${ }^{56}$ Pencerobohan Di Lahad Datu Pengajaran Berguna Kepada Malaysia-PM. Utusan Malaysia (2013) Op. Cit.

${ }^{57}$ Mohd Iskandar Ibrahim (2016) Cabaran Pastikan Perairan Negara Bebas Lanun. Berita Minggu. 13 March

58 T. Avineshwaran (2014) Op. Cit.

${ }^{59}$ Mahaizura Abd Malik (2020) COVID-19: ATM Pertingkat Kawalan Di Sempadan. Berita Harian 4 April

${ }^{60}$ Kogila Balakrishnan (2008). Op.cit m/s 135-155
} 
sistem antarabangsa ${ }^{61}$ Perspektif Pembangunan dan pemodenan ATM pasca Perang Dingin ternyata mempunyai perubahan yang signifikan di mana pembangunan ATM sebelum tahun 1990 lebih bersifat konvensional dan pasca Perang Dingin pembangunan ATM bersifat lebih strategik dengan diperlihatkan pemodenan ATM dilaksanakan dari pelbagai sudut namun ianya masih lagi belum cukup untuk membuktikan bahawa Malaysia benar-benar telah membangunkan dan memodenkan ATM secara drastik yang mampu memberikan kesan cegah rintang yang utuh bagi menjamin kelangsungan 'survival' dan keselamatan negara.

Perkembangan terkini di rantau ini telah menunjuk kepada beberapa cabaran dan ketidakpastian baru yang memberi kesan kepada pertahanan negara Malaysia. Walaupun Malaysia dan rantau ini pada umumnya mengalami kestabilan politik dan pertumbuhan ekonomi, isu-isu semasa terutamanya isuisu keselamatan bukan konvensional mula membentuk dan mempengaruhi sifat ancaman kepada pertahanan dan keselamatan negara. Pembangunan pertahanan terutamanya pemodenan ATM perlu dilakukan untuk menangani kemungkinan ancaman yang boleh menjejaskan kedaulatan, kemerdekaan dan integriti Malaysia. Program pembangunan ATM adalah penting memandangkan perubahan persekitaran strategik di seluruh dunia, di Wilayah Asia dan di dalam Malaysia sendiri. Persekitaran strategik ini telah memberikan kesan dan implikasi yang jauh ke atas keselamatan Malaysia. Bukan sahaja dari segi tuntutan bertindih ke atas kedaulatan kawasan maritim dan tanah dengan jiran-jiran negara, tetapi juga isu-isu yang berpotensi menimbulkan konflik yang disebabkan oleh perubahan global yang pesat yang banyak merumuskan perubahan dalam persekitaran strategik Malaysia.

\section{Rujukan}

Abdul Razak Abdullah Baginda. \& Rohana Mahmood (1995) Malaysia's Defence \& Foreign Policies. Petaling Jaya, Selangor Darul Ehsan, Malaysia. Pelanduk Publications.

Abu Sayyaf mengganas sejak 1990-an. Harian Metro. 26 April 2016

Andrew T. H. Tan (2014) The Global Arms Trade. A Handbook, Routledge Taylor \& Francis Group, New York, USA. ms. 23-24

Azmi Md Deros (2004). Super Hornet Pastikan Ruang Udara Lebih Selamat. Berita Harian. 15 Mei $2004 \mathrm{hlm} 5$.

Bradley R. Simpson (2013). Southeast Asia in the Cold War. Dalam Robert J. McMahon (Edt). The Cold War In The Third World. Oxford: Oxford University Press.hlm 52-58

Burchill, S., \& Linklater, A. (1996). Theories of international relations. New York: St. Martin's Press. Dato' Sri Mohd Najib Tun Abdul Razak (2006). semasa ucapan Penggulungan Bajet 2007 di Peringkat Dasar di Dewan Rakyat.

Datuk Dr Abdul Latiff Ahmad, Timbalan Menteri Pertahanan (2009). Teks Rasmi Ucapan Timbalan Menteri Pertahanan Sempena Lawatan Kerja Ke Kem Sri Pantai, Mersing pada 26 Julai 2009. hlm 18-19

Mohamad Faisol Keling (2016). Dasar Pertahanan Negara Malaysia : Analisis Ke Atas Prinsip Pertahanan Self-Reliance. Tesis Kajian Doktor Falsafah (PhD). Kolej Undang-Undang, Kerajaan Dan Pengajian Antarabangsa, Universiti Utara Malaysia. Februari

Farouk Kamal (2000). Defence Minister of Malaysia Najib Tun Abdul Razak Articulating Malaysia's Defence. Asian Defence and Diplomacy. Oktober. hlm 25

Hafidzul Hilmi Mohd Noor (2019). Scorpene Masih Berbisa. Harian Metro. 14 November 2019. https://www.hmetro.com.my/mutakhir/2019/11/517217/scorpene-masih-berbisa

Hendrik Wagenmakers (1995). The UN Register Of Convensional Arms, In Arms And Technology Transfer: Security and Economic Considerations Among Importing and Exporting States. New York: United Nations. hlm 75-81

Izwan Rozlin \& Ahmad Ismadi Ismai (2020).Al-Maunah Tewas Di Bukit Jenalik. Sinar Harian. 14 Mac 2020

Jaafar Kasim (2002) Influence Of Bureaucratic Politics On Ministry Of Defence Decision Making Process In Policy Formulation. Tesis. Faculty Of Social Science And Humanities: Universiti Kebangsaan Malaysia.hlm 32-36

\footnotetext{
${ }^{61}$ Muthiah Alagappa (1990). Op.cit m/s 186
} 
Jeneral Tan Sri Dato' Sri Azizan Ariffin TUDM (2009). Panglima Angkatan Tentera Ke-17. Maklumat diperolehi daripada Teks Rasmi Perintah Ulung Jeneral Tan Sri Dato' Sri Azizan Ariffin TUDM Panglima Angkatan Tentera Ke-17. 30 September 2009. hlm 2

Jurnal Tentera Darat Malaysia, Revolusi Dalam Hal Ehwal Ketenteraan, KEMENTAH: Sorotan Darat, Bil 43, Jun 2004, hIm 78.

Keling, M. F., Mohamad, M. H., \& Abdul Batau, M. F. (2016). Faktor dan Proses Pembangunan Dasar Pertahanan Negara Malaysia. Malaysian Journal of Social Sciences and Humanities (MJSSH), 1(3), 31 - 41.

Kementerian Pertahanan Malaysia (2006) Laporan Tahunan Kementerian Pertahanan Malaysia

Kenneth Waltz (1979). Theory Of International Politics. Massachusetts: Adison-Wesley. Hlm 131. Lihat juga John J. Mearsheimer (1995). The False Promise Of International Institutions. International Security, 19(3).

Khairil Annas Jusih (2016) Najib Razak Berjiwa Besar: Empat Dekad Menongkah Arus Kepimpinan \& Politik. Yayasan Penyelidikan Transformasi

Kogila Balakhrishnan (2008) Defence Industrialisation in Malaysia Development Challenges and the Revolution inMilitary Affairs. Security Challenges, Vol. 4, No. 4 (Summer 2008), pp. 135-155

Kogila Balakrishnan (2009). Malaysia's Defence Policy, Military Modernisation And National Security. Dalam Abdul Razak Baginda (pnyt). Malaysia's Defence \&Security Since 1957. Kuala Lumpur: Malaysia Strategic Research Centre. hlm 117-118

Liew Chin Tong (2019) Industri pertahanan pemangkin ekonomi negara. Sinar Harian. 4 April.

Liew Shan Lee (2016) Defence Asset Procurement Policy - Logistical Consideration. Mei 16 http://themalaysianpatriot.blogspot.com/2016/05/defence-asset-procurement-policy.html

Liew Shan Lee (2020) FPDA - Relevan? Atau Perencat Pembangunan Pertahanan Negara? 18 Januari.http://themalaysianpatriot.blogspot.com/2020/01/fpda-relevan-atau-perencatpembangunan.html

Lt Kol Soteto Bin Soejalmo (1999) How Successful Is The Modernization Of The Malaysia Armed Forces. Maktab Pertahanan Angkatan Tentera Malaysia. Edisi Terhad. Hlmn 1-9

M. Haniff Ismail (2008) Pembelian Aset Terpakai Satu Pandangan. Majalah Perajurt, Julai. ms 14-19

Mahaizura Abd Malik (2020) COVID-19: ATM Pertingkat Kawalan Di Sempadan. Berita Harian 4 April

Malaysia To Upgrade Military Assets to strengthen defence, Malaysia Outlook, 21 Mei 2017. http://www.malaysiaoutlook.com/malaysia-to-upgrade-military-assets-to-strengthen-defence-pmnajib/

Martin Griffiths dan Terry O'Callaghan (2002). International Relations, The Key Concepts. London: Routledge.

Mohd Basri Nordin (1999). Keperluan Industri Pertahanan Dalam Membentuk Perajurit ATM Abad Ke 21. Perajurit. Mei

Mohd Bustamam Mat Zain (2005). Comprehensive Security Policy - The Singapore Case. Bangi:UKM

Mohd Iskandar Ibrahim (2016) Cabaran Pastikan Perairan Negara Bebas Lanun. Berita Minggu. 13 March

Noraini Zulkifli (2016), Kepentingan Nasional Jepun Di Selat Melaka: Kerangka Teori Dan Konseptual.

P.K Sengupta dan Muhammad Fuad Mat Nor (2002). Cabaran ATM Dan Pemodenan TD. Perajurit. September. hlm 2-7

Pencerobohan Di Lahad Datu Pengajaran Berguna Kepada Malaysia-PM Utusan Malaysia. 12 Mac 2013

Platus PC-7 MKII (2008). dalam majalah Perajurit, Kuala Lumpur, Januari

Seven Al-Ma'unah Members Plead Guilty To Alternative Charge. Utusan Malaysia. 5 Disember 2000.

Shaharuddin Othman (2002). Malaysian Armed Forces Modernisation: Would It Enhance National Development? Faculty Of Social Sciences And Humanities: Universiti Kebangsaan Malaysia.

Sharanjit Singh (2018) Tun M-Putin Bincang Isu Jet Pejuang, Hubungan Dua Hala. Harian Metro. 14 November 2018

Sukma, R. and K.S. Nathan (2009) 'Globalization's Impact on Threat Perceptions and Defence Postures in Southeast Asia: Two Views', dalam G. Till, E. Chew and J. Ho (eds), Globalization and Defence in the Asia-Pacific, Abingdon: Routledge. Hlmn 90-120 
T. Avineshwaran (2014) Kawasan Kes Culik Di Resort Semporna Ada Banyak Sejarah Penculikan Lain. Akhbar Mstar. 3 April.

The Malaysian Insider (2015) Masyarakat Asean perlu faham ancaman keselamatan bukan tradisional, kata penganalisis sesi temubual dengan penganalisis Dr Azmi Hassan Pakar Geostrategis dari Universiti Teknologi Malaysia (UTM). https://www.yahoo.com/news/masyarakat-asean-perlufaham-ancaman-keselamatan-bukan-tradisional-051918085.html

Vishalache Balakrishnan (2013) Penilaian Program Latihan Khidmat Negara Dari Perspertif Pelatih: Satu Kajian Kes. Asia Pacific Journal of Educators, 28, 69-80

YB. Dato' Seri Hishammuddin Tun Hussein, Menteri Pertahanan (2014). Maklumat diperolehi daripada Teks Rasmi Perutusan YB. Dato' Seri Hishammuddin Tun Hussein, Menteri Pertahanan Malaysia. Majlis Perutusan Menteri Pertahanan Tahun 2014. Wisma Pertahanan, Kementerian Pertahanan pada 25 Februari 2014. hlm 4

Zabidi Mohamed (2010) Al-Maunah: Kebenaran Yang Sebenar (The Naked Truth). Malaysia. Zabidi Publication dan Nadzim Ahmad Jamalludin; Hassan Omar; Jalal Ali Abdul Rahim; Safuri Kamaruddin (2000) 146 senjata api dicuri. Berita Haria. 3 Julai. 